\title{
STRATEGI PEMASARAN KUE PIA ANYEN DI DESA SEA KECAMATAN PINELENG
}

\author{
Vika Singgita Findia Dien \\ Lyndon Reinhard Jacob Pangemanan \\ Celcius Talumingan
}

\begin{tabular}{ll}
\hline Naskah diterima melalui Website Jurnal Ilmiah agrisosioekonomi@unsrat.ac.id & $:$ Kamis, 17 Oktober 2019 \\
Disetujui diterbitkan & $:$ Kamis, 24 Oktober 2019 \\
\hline
\end{tabular}

\begin{abstract}
This study aims to look at the marketing strategy of "Anyen" pia cake in the sea village of Pineleng District. This research was conducted for 3 months, starting from March to June 2019. The data used in this study are primary data obtained from direct interviews with Anyen pia cake business owner, Mr. Lexy Pelealu and secondary data from 37 respondents of Anyen pia cake customers. fill out a questionnaire calculated on a Likert scale. The results of this study indicate that the marketing strategy for Anyen Pia is in the excellent category. Where aspects of the marketing mix of products $78.61 \%$, aspects of the marketing mix of prices $85.97 \%$, aspects of the marketing mix of places $81.07 \%$, and aspects of the marketing mix of promotion of $85.97 \% .{ }^{* e p r m *}$
\end{abstract}

Keywords: Strategy, Marketing, Pia Cake, Anyen, Sea Village, Pineleng District

ABSTRAK
Tujuan penelitian ini adalah untuk mengetahui strategi pemasaran pada kue pia "Anyen" di Desa Sea Kecamatan Pineleng. Penelitian ini dilaksanakan selama 3 bulan, mulai dari bulan Maret sampai Juni 2019. Data yang digunakan dalam penelitian ini adalah data primer yang diperoleh dari wawancara langsung kepada pemilik usaha kue pia Anyen, Bapak Lexy Pelealu dan data sekunder dari 37 responden pelanggan kue pia Anyen yang mengisi kuesioner yang dihitung dengan skala likert. Hasil dari penelitian ini mengindikasi bahwa strategi pemasaran kue pia Anyen dalam kategori sangat baik. Dimana aspek bauran pemasaran produk 78,61\%, aspek bauran pemasaran harga $85,97 \%$, aspek bauran pemasaran tempat $81,07 \%$, dan aspek bauran pemasaran promosi $85,97 \%$. ${ }^{*}$ prm*

Kata kunci: strategi, pemasaran, kue pia, anyen, Desa Sea, Kecamatan Pineleng

\section{PENDAHULUAN}

\section{Latar Belakang}

Kesuksesan sebuah bisnis atau usaha adalah dengan cara memanfaatkan peluang yang ada sekarang dan banyak diminati oleh masyarakat, para pelaku usaha harus lebih kreatif dalam menjalankan strategi sebuah bisnis. Disamping pelaku usaha harus kreatif dan harus mampu melakukan inovasi pada produk kegunaan pelaku usaha melakukan kreativitas dan inovasi adalah untuk kelangsungan hidup usahanya. Usaha kecil adalah usaha ekonomi produktif yang berdiri sendiri, yang dilakukan oleh orang perorangan atau badan usaha yang bukan merupakan anak perusahan atau bukan anak cabang yang dimiliki, dikuasai atau menjadi 
bagian, baik langsung maupun tidak langsung, dari usaha menengah atau usaha besar yang memenuhi kriteria usaha kecil sebagaimana dimaksud dalam UU tersebut.

Usaha kue pia merupakan salah satu usaha yang mempunyai prospek bisnis yang bagus ke depan. Usaha kue pia berperan dalam mendorong pendapatan sehingga meningkatkan taraf hidup dan kesejahteraan. Persaingan bisnis yang sudah semakin kompetitif membuat para pelaku usaha secara berkesinambungan berusaha menyesuaikan diri terhadap perubahan yang terjadi pada zaman globalisasi saat ini. Jika pelaku usaha tidak bisa menyesuaikan diri dengan pasar yang ada maka usaha tersebut bias mengalami kegagalan.

Anyen merupakan usaha kue pia di desa Sea Kecamatan Pineleng dengan pemilik bapak Martin Lexy Pelealu dan memiliki tujuh orang karyawan dimana enam orang membuat kue pia dan satu orang mengoven kue pia. Kue pia Anyen memiliki tiga varian rasa yaitu rasa cokelat, rasa keju, dan rasa cokelat keju, Kue pia Anyen di pasarkan dengan harga Rp. 40.000-Rp. $80.000 /$ box. Pemasaran kue pia ini dijual di warung milik sendiri, warung sekitar tempat usaha dan sampai di daerah Manado, Minahasa, Minahasa Selatan, Minahasa Utara dan Bitung.

Menghadapi persaingan di dalam mendapatkan pelanggan, Industri rumah tangga Pia Anyen menyadari tidaklah mudah tanpa ada sebuah tindakan nyata berupa bekerja keras dengan menggunakan strategi yang tepat untuk meningkatkan jumlah pelanggan. Strategi merupakan kunci penting terhadap keberhasilan sebuah perusahaan dalam meraih pelanggan. Strategi adalah upaya yang dimiliki individu dan unsur-unsur yang ada dalam organisasi untuk memiliki keterampilan dan memanfaatkan sumber daya sesuai dengan kondisi lingkungan kerja untuk mendapatkan keuntungan yang optimal.

\section{Rumusan Masalah}

Bagaimana strategi pemasaran yang dilakukan dalam memasarkan kue pia Anyen di Desa Sea Kecamatan Pineleng ?

\section{Tujuan Penelitian}

Untuk mengetahui dan menganalisis strategi pemasaran pada kue pia "Anyen" Desa Sea Kecamatan Pineleng.

\section{Manfaat Penelitian}

Manfaat penulisan ini yaitu :

- Bagi pemilik usaha, Untuk bahan masukan dan evaluasi bagi produsen kue pia ANYEN dalam strategi pemasaran.

- Bagi peneliti, untuk menambah pengalaman dan merupakan pengimplementasian ilmu pengetahuan yang telah didapatkan selama perkuliahan

- Bagi pembaca, untuk memberikan informasi tambahan dalam menggunakan studi yang relevan di masa yang akan datang.

\section{METODE PENELITIAN}

\section{Lokasi dan Waktu Penelitian}

Penelitian ini dilaksanakan di "Anyen" Desa Sea Kecamatan Pineleng. Sedangkan waktu penelitian dilakukan pada bulan Maret 2019 selesai pada bulan Juni 2019.

\section{Metode Pengumpulan Data}

Data yang digunakan dalam penelitian ini yaitu data primer yang diperoleh dari produsen dan konsumen kue pia ANYEN dan data sekunder diperoleh dari buku, internet, dan jurnal.

\section{Metode Pengambilan Sampel}

Metode pengambilan sampel dilakukan dengan menggunakan teknik accidental sampling atau teknik sampel berdasarkan kebetulan yaitu siapa saja yang secara kebetulan/incidental yang ditemukan dapat digunakan sebagai sampel sesuai untuk sumber data (Rahmat, 2012).

\section{Konsep Pengukuran Variabel}

Adapun yang terjadi konsep pengukuran variable dalam penelitian ini adalah sebagai berikut:

1. Karakteristik Responden

a. Umur (tahun)

b. Jenis Kelamin (Laki-laki/ Perempuan)

c. Pekerjaan (profesi responden pada saat wawancara dilaksanakan) 
2. Mengetahui penerapan bauran pemasaran 4P :

1. Produk (product) Meliputi :

- Rasa produk yang bervariasi

- Bahan yang aman serta tekstur produk yang diinginkan

- Tampilan fisik/variasi produk

- Kemasan yang menarik

2. Harga (price) Meliputi :

- Keterjangkauan harga

- Kesesuaian harga dengan produk yang ditawarkan

- Potongan Harga

3. Tempat (place) Meliputi :

- Dsitribusi produk dengan cepat

- Jasa pesan antar/delivarry order

- Lokasi yang strategis

4. Promosi (promotion) Meliputi :

- Upaya memperkenalkan produk

- Media promosi bervariasi

- Promosi langsung dari produsen ke konsumen

\section{Metode Analisis Data}

Teknik analisis data yang digunakan yaitu metode analisis deskriptif kuantitatif. Data yang telah terkumpul dilakukan tabulasi, yaitu memberikan nilai (scoring) sesuai dengan sistem yang ditetapkan menggunakan skala likert. Instrumen pertanyaan disusun sebanyak 13 peryataan. Adapun penggunaan skala yaitu 1-5 untuk setiap jawaban responden selanjutnya dibagikan dalam lima kategori yakni :

Skor $5=\mathrm{SP} \quad$ Skor $4=\mathrm{P} \quad$ Skor $3=\mathrm{CP}$

Skor $2=$ TP $\quad$ Skor $1=$ STP

Dengan cara perhitungan skor masing-masing pertanyaan:

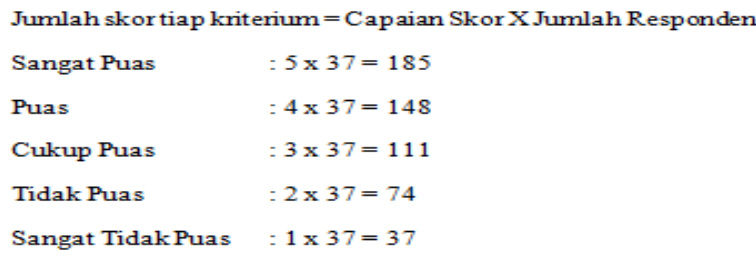

Jumlah skor ideal setiap item pertanyaan, skor tertinggi 185 (SB) dan jumlah skor terendah 37 (STB). Dengan penilaian:

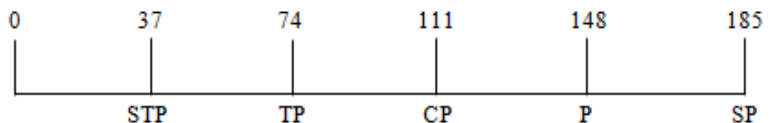

Untuk mengetahui karakteristik masingmasing variabel penelitian digunakan rumus indeks (\%) disetiap aspek bauran pemasaran yang dihasilkan dalam pengambilan data.

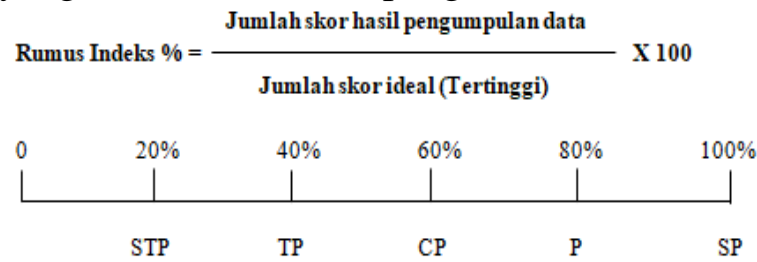

Keterangan : kriteria interpretasi skor

Angka 0\%-20\%= Sangat Tidak Puas

Angka $21 \%-40 \%=$ Tidak Puas

Angka $41 \%-60 \%=$ Cukup Puas

Angka $61 \%-80 \%=$ Puas

Angka $81 \%-100 \%=$ Sangat Puas

\section{PEMBAHASAN}

\section{Deskripsi Umum Usaha Kue Pia Anyen}

Usaha kue pia Anyen mulai dirintis oleh bapak Marthin Lexy Pelealu sejak tahun 2013, terletak di Desa Sea Kecamatan Pineleng Kabupaten Minahasa. Usaha ini bergerak dibidang industri pengolahan kue pia selama enam (6) tahun dan memiliki tiga variasi rasa yaitu rasa cokelat, rasa keju dan rasa cokelat keju dengan dua bentuk yaitu rasa cokelat dan rasa keju dengan bentuk bulat dan rasa cokelat keju dengan bentuk memanjang. Anyen memiliki tujuh (7) orang karyawan enam karyawan wanita membuat kue pia dan satu karyawan laki-laki mengoven kue pia.

Bahan baku pembuatan kue pia dibeli dari supermarket dan pasar tradisional atau tempat lainnya yang mudah dijangkau dengan harga yang terjangkau. Bahan baku yang digunakan yaitu tepung, telur, mentega, minyak goreng, gula pasir, air dan garam untuk adonan kulit dan tapioka, minyak, susu, 
cokelat dan keju untuk isian rasa kue pia. Alat-alat yang digunakan dalam proses pembuatan kue pia yaitu pisau iris, wadah untuk adonan kue pia, meja panjang, dan oven. Proses pembuatan kue pia dengan mencampurkan semua bahan kulit menjadi satu secara manual atau menggunakan tangan. Setelah tercampur diamkan selama lima menit dan langsung di letakan di atas meja dan giling tipis adonan kulit yang sudah dibuat, lalu tambahkan bahan isi di tengahtengahnya. Tutup kue pia dan bentuk sesuai rasa, setelah itu oven adonan selama 10-15 menit dengan suhu 160 derajat.

Setiap karyawan dapat membuat $6 \mathrm{~kg}$ adonan kue pia, dan $1 \mathrm{~kg}$ adonan kue pia menghasilkan 150 buah kue pia. Dalam sehari Anyen dapat memproduksi 5.400 buah kue pia dengan berat 10 gr untuk setiap 1 buah kue pia. Harga jual kue pia Anyen Rp.800 untuk satu kue pia. Ada tiga jenis kemasan kue pia "Anyen" dengan harga yang berbeda yaitu kemasan isi 50 dengan harga Rp.40.000, isi 75 dengan harga Rp.60.000 dan isi 100 dengan harga Rp.80.000. Kue pia Anyen sudah dipasarkan di warung-warung dekat lokasi produksi, dan di warung-warung daerah manado, Minahasa Selatan, Minahas Utara dan Minahasa Tenggara, dan Minahasa dan dijual kembali dengan harga Rp. 1.000 untuk satu buah kue pia.

\section{Bauran Pemasaran Kue Pia Anyen}

\section{Produk (Product)}

Anyen memproduksi tiga varian rasa kue pia yaitu rasa cokelat, rasa keju dan rasa cokelat keju dan dibuat dengan bahan yang mudah didapat serta tidak menggunakan bahan pengawet ataupun bahan kimia lainnya dan dikemas dalam toples plastik yang transparan serta bersih dan rapih.

\section{Harga (Price)}

Produk kue pia "Anyen" memiliki harga Rp. 800,00/satu kue pia dan harga berbeda tergantung banyaknya isi kue pia dalam kemasan. Kemasan dengan isi 50 kue pia diberi harga Rp. 40.000,00 dan isi 75 kue pia diberi harga Rp. 60.000,00 dan isi 100 kue pia dengan harga Rp. 80.000,00.

\section{Tempat (Place)}

Tempat atau lokasi usaha kue pia "Anyen" sejak 2013 sampai saat ini berada di Desa Sea Kecamatan Pineleng Kabupaten Minahasa. Produk kue pia sudah bisa ditemukan dimana saja diantaranya yaitu, warungwarung di Desa Sea, rumah makan dan toko kecil serta warung-warung sekitar kota Manado, dan warungwarung sekitar Kabupaten Minahasa Selatan, Minahasa Utara, Minahasa Tenggara, serta Minahasa.

\section{Promosi (Promotion)}

Promosi yang digunakan ANYEN yaitu mendatangi langsung calon pembeli atau menawarkan langsung kepada konsumen. Belum ada promosi lewat media cetak ataupun media sosial.

\section{Umur}

\section{Karakteristik Responden}

Seseorang akan mengalami perubahan jenis maupun jumlah barang atau jasa yang akan dikonsumsi seiring dengan bertambahnya umur. Umur diukur dalam satuan tahun. Tabel dibawah menunjukkan hasil pengamatan terhadap umur responden pada pelanggan kue pia ANYEN.

\begin{tabular}{llll}
\multicolumn{4}{l}{ Tabel 1. Karakteristik Responden Berdasarkan Usia } \\
\hline No. & Usia(Tahun) & Jumlah Responden & Presentase(\%) \\
\hline 1 & $15-35$ & 16 & $43 \%$ \\
2 & $36-45$ & 10 & $27 \%$ \\
3 & $>46$ & 11 & $30 \%$ \\
\hline & Total & 37 & $100 \%$ \\
\hline
\end{tabular}

Sumber: Diolah dari data primer, 2019

Tabel 1 menunjukkan bahwa responden yang berusia 15-35 tahun sebanyak 16 orang (43\%), responden yang berusia 36-45 tahun sebanyak 10 orang $(27 \%)$, dan responden yang berusia >46 tahun sebanyak 11 orang $(30 \%)$. Hal ini juga dikarenakan kue pia bisa dikonsumsi oleh semua umur.

\section{Jenis Kelamin}

Faktor jenis kelamin dapat mempengaruhi keputusan pembelian seseorang. Tabel berikut menunjukkan hasil pengamatan terhadap jenis kelamin pada responden kue pia ANYEN :

Tabel 2. Karakteristik Responden Berdasarkan Jenis Kelamin

\begin{tabular}{cccc}
\hline No. & Jenis Kelamin & Jumlah Responden & Presentase(\%) \\
\hline 1 & Perempuan & 26 & $70 \%$ \\
2 & Laki-laki & 11 & $30 \%$ \\
\hline & Total & 37 & $100 \%$ \\
\hline
\end{tabular}

Sumber: Diolah dari data primer, 2019 
Tabel 2 menunjukkan jenis kelamin yang paling dominan membeli produk pia Anyen adalah perempuan yaitu sebanyak 26 orang dengan persentase $70 \%$. Sedangkan laki-laki sebanyak 11 orang dengan persentase $30 \%$.

\section{Pekerjaan Responden}

Pola konsumsi seseorang juga dipengaruhi oleh pekerjaannya. Para pemasar mencoba mengidentifikasi kelompokkelompok pekerjaan atau jabatan yang memiliki kecenderungan minat diatas ratarata dalam produk dan jasa mereka. Tabel berikut menunjukkan hasil pengamatan terhadap jenis pekerjaan pada responden kue pia ANYEN:

Tabel 3. Karakteristik Responden Berdasarkan Jenis Pekerjaan

\begin{tabular}{llcc}
\hline No. & Pekerjaan & $\begin{array}{c}\text { Jumlah } \\
\text { Responden }\end{array}$ & Presentase(\%) \\
\hline 1 & Pelajar & 2 & $5 \%$ \\
2 & Mahasiswa & 3 & $8 \%$ \\
3 & Pegawai Swasta & 2 & $5 \%$ \\
4 & Wiraswasta & 10 & $27 \%$ \\
5 & Pegawai Negeri Sipil & 4 & $11 \%$ \\
6 & Lainnya & 16 & $43 \%$ \\
\hline & Total & 37 & $100 \%$ \\
\hline
\end{tabular}

Sumber: Diolah dari data primer, 2019

Tabel 3 menunjukkan responden dengan jenis pekerjaan paling banyak adalah lainnya yaitu sebanyak 16 orang dengan persentase $43 \%$ dan paling sedikit sebagai pelajar yaitu sebanyak 2 orang dengan persentase $5 \%$.

\section{Penilaian Responden Terhadap Usaha Kue Pia Anyen \\ Produk (Product)}

\section{Variasi Rasa Kue Pia}

Titik perasa dari lidah adalah kemampuan mendeteksi dasar yaitu manis, asam, asin, pahit. Dalam makanan tertentu empat rasa ini digabungkan sehingga menjadi satu rasa yang unik dan menarik untuk dinikmati. Hasil penelitian menurut responden mengenai rasa kue pia dapat dilihat pada tabel berikut :
Tabel 4. Penilaian Responden terhadap Variasi Rasa Kue Pia ANYEN

\begin{tabular}{lcccc}
\hline Jawaban & Skor & $\begin{array}{c}\text { Jumlah } \\
\text { Responden }\end{array}$ & Presentase(\%) & $\begin{array}{c}\text { Total } \\
\text { Skor }\end{array}$ \\
\hline Sangat Puas & 5 & 18 & $49 \%$ & 90 \\
Puas & 4 & 13 & $35 \%$ & 52 \\
Cukup Puas & 3 & 5 & $14 \%$ & 15 \\
Tidak Puas & 2 & 1 & $3 \%$ & 2 \\
Sangat Tidak Puas & 1 & 0 & $0 \%$ & 0 \\
\hline Total & 37 & $100 \%$ & 159 \\
\hline Sumber: Diolah dari data primer, 2019 &
\end{tabular}

Tabel 4 diatas menunjukkan bahwa 18 orang (49\%) menilai sangat puas dan 13 orang (35\%) menilai puas, dan 5 orang (14\%) menilai cukup puas, 1 orang (3\%) menilai tidak puas. Jumlah total skor seluruhnya yaitu 159 .

Secara persentase, adalah sebagai berikut:

\section{$\frac{159}{1.5} \times 100 \%=86 \%$ berati penulaian resoonden temadap vanasa rasa kue pia Anyen sangatpuas.}

\section{Bahan dan Tekstur Kue Pia}

Bahan dan tekstur merupakan merupakan sifat yang sangat penting, baik dalam makanan segar maupun hasil olahan. Hasil penelitian menurut responden mengenai bahan dan tekstur kue pia dapat dilihat pada tabel berikut :

Tabel 5. Penilaian Responden terhadap Bahan dan Tekstur Kue Pia Anyen

\begin{tabular}{lcccc}
\hline Jawaban & Skor & $\begin{array}{c}\text { Jumlah } \\
\text { Responden }\end{array}$ & $\begin{array}{c}\text { Persentase } \\
(\%)\end{array}$ & $\begin{array}{c}\text { Total } \\
\text { Skor }\end{array}$ \\
\hline Sangat Puas & 5 & 9 & $24 \%$ & 45 \\
Puas & 4 & 23 & $62 \%$ & 92 \\
Cukup Puas & 3 & 5 & $14 \%$ & 15 \\
Tidak Puas & 2 & 0 & $0 \%$ & 0 \\
Sangat Tidak Puas & 1 & 0 & $0 \%$ & 0 \\
\hline Total & & 37 & $100 \%$ & 152 \\
\hline Sumber: Diolah dari data primer, 2019 & &
\end{tabular}

Tabel 5 menunjukkan bahwa 9 orang (24\%) menilai sangat puas, 23 orang $(62 \%)$ menilai puas, dan 5 orang $(14 \%)$ menilai cukup puas. Dengan jumlah total skor yaitu 152.

Secara persentase, adalah sebagai berikut: $\frac{152}{185} \times 100 \%=82 \%$ Menunjukkan responden menilai bahan dan tekstur kue pia Anyen sangat puas. 


\section{Variasi Ukuran dan Bentuk Kue Pia}

Tujuan seseorang mengkonsumsi makanan adalah untuk memenuhi kebutuhan pada tubuhnya. Pengusaha harus dapat menentukan secara tepat ukuran pada setiap porsi yang disajikan sehingga dapat memuaskan konsumen dan tetap memperoleh keuntungan dari setiap porsi yang dijual.

Hasil penelitian menurut responden mengenai ukuran kue pia dapat dilihat pada tabel berikut :

Tabel 6. Penilaian Responden terhadap Variasi Bentuk Kue Pia Anyen

\begin{tabular}{lcccc}
\hline Jawaban & Skor & $\begin{array}{c}\text { Jumlah } \\
\text { Responden }\end{array}$ & $\begin{array}{c}\text { Persentase } \\
(\%)\end{array}$ & $\begin{array}{c}\text { Total } \\
\text { Skor }\end{array}$ \\
\hline Sangat Puas & 5 & 7 & $19 \%$ & 35 \\
Puas & 4 & 17 & $46 \%$ & 68 \\
Cukup Puas & 3 & 12 & $32 \%$ & 36 \\
Tidak Puas & 2 & 1 & $3 \%$ & 2 \\
Sangat Tidak Puas & 1 & 0 & $0 \%$ & 0 \\
\hline Total & 37 & $100 \%$ & 141 \\
\hline Sumber: Diolah dari data primer, 2019
\end{tabular}

Tabel 6 , menunjukkan bahwa 7 orang (19\%) menilai sangat puas, 17 orang (46\%) menilai puas, 12 orang (32\%) menilai cukup puas, serta 1 orang (3\%) memilih sangat tidaak puas karena tidak menyukai ukuran yang kecil. Dengan jumlah total skor yaitu 141 .

Secara persentase, adalah sebagai berikut:

$\frac{141}{185} \times 100 \%=76,22 \%$ Berdasarkan presentase, skor tersebut berada di kriteria puas.

\section{Kemasan}

Kemasan atau pembungkus mempunyai arti yang penting, karena tidak hanya digunakan sebagai pelindung terhadap produk, tetapi juga digunakan untuk dapat menyenagnkan dan menarik langganan.

Hasil penelitian menurut responden mengenai kemasan Pia Anyen dapat dilihat pada tabel berikut :

Tabel 7. Penilaian Responden terhadap Kemasan Kue Pia Anyen

\begin{tabular}{lcccc}
\hline Jawaban & Skor & $\begin{array}{c}\text { Jumlah } \\
\text { (orang) }\end{array}$ & $\begin{array}{c}\text { Persentase } \\
(\%)\end{array}$ & $\begin{array}{c}\text { Total } \\
\text { Skor }\end{array}$ \\
\hline Sangat Puas & 5 & 5 & $14 \%$ & 25 \\
Puas & 4 & 13 & $35 \%$ & 52 \\
Cukup Puas & 3 & 15 & $41 \%$ & 45 \\
Tidak Puas & 2 & 4 & $11 \%$ & 8 \\
Sangat Tidak Puas & 1 & 0 & $0 \%$ & 0 \\
\hline Total & & 37 & $100 \%$ & 130 \\
\hline
\end{tabular}

Sumber : Diolah dari data primer, 2019
Tabel 7 diatas menunjukkan bahwa 5 orang (14\%) menilai sangat puas, 13 orang $(35 \%)$ menilai puas, 15 orang (41\%) menilai cukup puas, serta 4 orang $(11 \%)$ memilih sangat tidak puas. Dengan jumlah total skor yaitu 130 .

Secara persentase, adalah sebagai berikut:

$\frac{130}{185} \times 100 \%=70,23 \%$ Skor tersebut berada di kriteria puas dengan persentase $70,23 \%$.

\section{Bauran Pemasaran Kue Pia Terhadap Produk}

Hasil penelitian menurut responden mengenai Bauran Pemasaran Produk Kue Pia dapat dilihat pada tabel berikut :

Tabel 8. Rekapitulasi dari Total Skor Bauran Pemasaran Kue Pia Terhadap Produk

\begin{tabular}{llccc}
\hline No. & Pernyataan & $\begin{array}{c}\text { Total } \\
\text { Skor }\end{array}$ & $\begin{array}{c}\text { Persentase } \\
(\%)\end{array}$ & Kategori \\
\hline 1 & Variasi Rasa & 159 & 86 & Sangat Puas \\
2 & Bahan dan Tekstur & 152 & 82 & Sangat Puas \\
3 & Variasi Bentuk & 141 & 76,22 & Puas \\
4 & Kemasan & 130 & 70,23 & Puas \\
\hline & Jumlah & 582 & 314,45 & \\
& Rata-rata & 145,5 & 78,61 & Puas \\
\hline
\end{tabular}

Sumber : Diolah dari data primer, 2019

Pada tabel 8 dijelaskan bahwa rata-rata tanggapan responden terhadap produk adalah $78,61 \%$ dengan kategori puas. Indikator produk yang memperoleh penilaian yang tinggi dari responden ialah variasi rasa yaitu $86 \%$ dengan kriteria sangat puas.

Sedangkan indikator produk yang memperoleh penilaian yang terendah dari responden adalah kemasan yaitu $70,23 \%$ dengan kriteria puas.

\section{Harga}

\section{Keterjangkauan Harga}

Keterjangkauan harga merupakan harga yang bisa diterima oleh responden dan pelanggan. Ada beberapa jenis harga kue pia saat ini.

Hasil penelitian menurut responden mengenai Keterjangkauan Harga kue pia dapat dilihat pada tabel berikut :

Tabel 9. Penilaian Responden terhadap Keterjangkauan Harga Kue

\begin{tabular}{lcccc} 
Pia Anyen & Skor & $\begin{array}{c}\text { Jumlah } \\
\text { Responden }\end{array}$ & $\begin{array}{c}\text { Persentase } \\
(\%)\end{array}$ & $\begin{array}{c}\text { Total } \\
\text { Skor }\end{array}$ \\
\hline Sangat Puas & 5 & 28 & $76 \%$ & 140 \\
Puas & 4 & 9 & $24 \%$ & 36 \\
Cukup Puas & 3 & 0 & $0 \%$ & 0 \\
Tidak Puas & 2 & 0 & $0 \%$ & 0 \\
Sangat Tidak Puas & 1 & 0 & $0 \%$ & 0 \\
\hline Total & \multicolumn{5}{l}{$100 \%$} & 176 \\
\hline Sumber: Diolah dari data primer, 2019 &
\end{tabular}


Tabel 9 diatas menunjukkan bahwa 28 orang $(76 \%)$ menilai sangat puas, 9 orang $(24 \%)$ menilai puas. Dengan jumlah total skor yaitu 176. Secara persentase, adalah sebagai berikut:

$\frac{176}{185} \times 100 \%=95,13 \%$ Skor tersebut berada di kriteria sangat puas dengan persentase $95,13 \%$.

\section{Kesesuaian Harga Dengan Produk Yang Ditawarkan}

Kesesuaian harga yaitu harga yang ditawarkan produsen yang sesuai dengan produk yang dapat diperoleh konsumen.

Hasil penelitian menurut responden mengenai Kesesuaian harga dengan produk yang ditawarkan dapat dilihat pada tabel berikut :

Tabel 10. Penilaian Responden terhadap Kesesuaian Harga dengan Kualitas Produk Kue Pia Anyen

\begin{tabular}{lcccc}
\hline Jawaban & Skor & $\begin{array}{c}\text { Jumlah } \\
\text { Responden }\end{array}$ & $\begin{array}{c}\text { Persentase } \\
(\%)\end{array}$ & Total Skor \\
\hline Sangat Puas & 5 & 23 & $62 \%$ & 115 \\
Puas & 4 & 14 & $38 \%$ & 56 \\
Cukup Puas & 3 & 0 & $0 \%$ & 0 \\
Tidak Puas & 2 & 0 & $0 \%$ & 0 \\
Sangat Tidak Puas & 1 & 0 & $0 \%$ & 0 \\
\hline Total & & 37 & $100 \%$ & 171 \\
\hline
\end{tabular}

Sumber: Diolah dari data primer, 2019

Tabel 10 diatas menunjukkan bahwa 23 orang $(62 \%)$ menilai sangat puas, 14 orang (38\%) menilai puas. Dengan jumlah total skor yaitu 171. Secara persentase, adalah sebagai berikut:

$\frac{171}{185} \times 100 \%=92,43 \%$ Skor tersebut berada di kriteria sangat puas dengan presentase.

\section{Potongan Harga}

Potongan harga adalah pengurangan dari harga dari harga normal dalam periode tertentu.

Hasil penelitian menurut responden mengenai potongan harga kue pia dapat dilihat pada tabel berikut :

Tabel 11. Penilaian Responden Terhadap Potongan Harga

\begin{tabular}{lcccc}
\hline Jawaban & Skor & $\begin{array}{c}\text { Jumlah } \\
\text { Responden }\end{array}$ & $\begin{array}{c}\text { Persentase } \\
(\%)\end{array}$ & $\begin{array}{c}\text { Total } \\
\text { Skor }\end{array}$ \\
\hline Sangat Puas & 5 & 6 & $16 \%$ & 30 \\
Puas & 4 & 14 & $38 \%$ & 56 \\
Cukup Puas & 3 & 13 & $35 \%$ & 39 \\
Tidak Puas & 2 & 3 & $8 \%$ & 6 \\
Sangat Tidak Puas & 1 & 1 & $3 \%$ & 1 \\
\hline Total & 37 & $100 \%$ & 132 \\
\hline Sumber: Diolah dari data primer, 2019 & &
\end{tabular}

Agrisosioekonomi:

Jurnal Transdisiplin Pertanian (Budidaya Tanaman, Perkebunan, Kehutanan, Peternakan, Perikanan), Sosial dan Ekonomi
Tabel 11 menunjukkan bahwa 16 orang (16\%) memilih sangat puas, 14 orang (38\%) memilih puas, 13 orang (35\%) memilih cukup puas, 3 orang $(8 \%)$ memilih tidak Puas dan 1 orang $(3 \%)$ memilih sangat tidak puas. Dengan jumlah skor yaitu 132 .

$\frac{132}{185} \times 100 \%=71,35 \%$

Skor tersebut berada di kriteria puas.

\section{Bauran Pemasaran Kue Pia Terhadap Harga}

Hasil penelitian menurut responden mengenai Bauran Pemasaran Harga Kue Pia dapat dilihat pada tabel berikut :

Tabel 12. Rekapitulasi dari Total Skor Bauran Pemasaran Kue Pia Terhadap Harga

\begin{tabular}{llccc}
\hline No. & Pernyataan & $\begin{array}{c}\text { Total } \\
\text { Skor }\end{array}$ & $\begin{array}{c}\text { Persentas } \\
\text { e }(\%)\end{array}$ & Kategori \\
\hline \multirow{2}{*}{1} & $\begin{array}{l}\text { Keterjangkauan } \\
\text { harga }\end{array}$ & 176 & 95,13 & Sangat Puas \\
& $\begin{array}{l}\text { Kesesuaian } \\
\text { harga dengan } \\
\text { kualitas }\end{array}$ & 171 & 91,43 & Sangat Puas \\
3 & Potongan Harga & 132 & 71,35 & Puas \\
& Jumlah & 479 & 257,91 & \\
& Rata-rata & 159,67 & 85,97 & Sangat Puas \\
\hline
\end{tabular}

Tabel 12 diatas menunjukkan bahwa ratarata tanggapan responden terhadap harga adalah $85,97 \%$ dengan kriteria sangat puas. Indikator harga yang memperoleh penilaian yang tinggi dari responden adalah keterjangkauan harga yaitu 95,13\% dengan kriteria sangat puas dan penilaian terendah dari responden adalah potongan harga yaitu $71,35 \%$ dengan kriteria cukup puas.

\section{Tempat (Place)}

\section{Proses Distribusi Produk}

Distribusi adalah kegiatan menyalurkan suatu produk, baik itu barang atau jasa, dari produsen ke konsumen sehingga produk tersebut tersebar luas. Hasil penelitian menurut responden mengenai proses distrihusi dapat dilihat pada tabel berikut :

\begin{tabular}{lcccc}
\multicolumn{5}{l}{ Tabel 13. Penilaian Responden Terhadap Proses Distribusi } \\
\hline Jawaban & Skor & $\begin{array}{c}\text { Jumlah } \\
\text { Responden }\end{array}$ & $\begin{array}{c}\text { Persentase } \\
(\%)\end{array}$ & $\begin{array}{c}\text { Total } \\
\text { Skor }\end{array}$ \\
\hline Sangat Puas & 5 & 13 & $35 \%$ & 65 \\
Puas & 4 & 13 & $35 \%$ & 52 \\
Cukup Puas & 3 & 9 & $24 \%$ & 27 \\
Tidak Puas & 2 & 2 & $5 \%$ & 4 \\
Sangat Tidak Puas & 1 & 0 & $0 \%$ & 0 \\
\hline Total & & 37 & $100 \%$ & 148 \\
\hline Sumber: Diolah dari data primer, 2019
\end{tabular}


Tabel 13 menunjukkan bahwa 13 responden $(13 \%)$ memilih sangat puas, 13 responden (35\%) memilih puas, 9 orang (24\%) memilih cukup puas dan 2 orang (5\%) memilih tidak puas. Dengan jumlah total skor yaitu 148 .

$\frac{148}{185} \times 100 \%=80 \%$ Skor tersebut berada di kriteria sangat puas.

\section{Jasa Pesan Antar}

Hasil penelitian menurut responden terhadap jasa pesan antar kue pia ANYEN dapat dilihat pada table berikut:

Tabel 14. Penilaian Responden Terhadap Jasa Pesan

\begin{tabular}{lcccc} 
Antar & \multicolumn{5}{c}{ Jumlah } \\
Jawaban & Skor & $\begin{array}{c}\text { Persentase } \\
(\%)\end{array}$ & $\begin{array}{c}\text { Total } \\
\text { Skor }\end{array}$ \\
\hline Sangat Puas & 5 & 16 & $43 \%$ & 80 \\
Puas & 4 & 17 & $46 \%$ & 68 \\
Cukup Puas & 3 & 3 & $8 \%$ & 9 \\
Tidak Puas & 2 & 0 & $0 \%$ & 0 \\
Sangat Tidak Puas & 1 & 1 & $3 \%$ & 1 \\
\hline Total & 37 & $100 \%$ & 158 \\
\hline Sumber: Diolah dari data primer, 2019
\end{tabular}

Tabel 14 menunjukkan bahwa 16 responden $(43 \%)$ memilih sangat puas, 17 responden $(46 \%)$ memilih puas, 3 orang $(8 \%)$ memilih cukup puas. Dengan total skot yaitu 158.

$\frac{158}{185} \times 100 \%=85,40 \%$ Skor tersebut berada di kriteria sangat puas dengan persentase $85,40 \%$.

\section{Lokasi Strategis}

Dalam memilih lokasi usahanya, pemilik lokasi usaha harus mempertimbangkan faktorfaktor pemilihan lokasi, karena lokasi usaha akan berdampak pada kesuksesan usaha itu sendiri. Hasil penelitian menurut responden mengenai lokasi kue pia ANYEN dapat dilihat pada tabel berikut :

Tabel 15. Penilaian Responden terhadap Lokasi Kue

\begin{tabular}{lcccc}
\multicolumn{5}{c}{ Pia Anyen } \\
\hline Jawaban & Skor & $\begin{array}{c}\text { Jumlah } \\
\text { Responden }\end{array}$ & $\begin{array}{c}\text { Persentase } \\
(\%)\end{array}$ & $\begin{array}{c}\text { Total } \\
\text { Skor }\end{array}$ \\
\hline Sangat Puas & 5 & 8 & $22 \%$ & 40 \\
Puas & 4 & 17 & $46 \%$ & 68 \\
Cukup Puas & 3 & 12 & $32 \%$ & 36 \\
Tidak Puas & 2 & 0 & $0 \%$ & 0 \\
Sangat Tidak Puas & 1 & 0 & $0 \%$ & 0 \\
\hline Total & 37 & $100 \%$ & 144 \\
\hline Sumber: Diolah dari dat primer, 2019
\end{tabular}

Tabel 15 menunjukkan bahwa 8 responden (22\%) memilih sangat puas, 17 rsponden $(46 \%)$ memilih puas dan 12 responden (32\%) memilih cukup puas. Dengan total skor yaitu 144 .

$\frac{144}{185} \times 100 \%=77,83 \%$ Skor tersebut berada pada kriteria $77,83 \%$ yaitu puas.

\section{Bauran Pemasaran Kue Pia Anyen terhadap Tempat}

Bauran Pemasaran Lokasi/Tempat Produksi kue pia ANYEN dapat dilihat pada tabel berikut :

Tabel 16. Rekapitulasi dari Total Skor Bauran Pemasaran Kue

\begin{tabular}{llccc}
\multicolumn{5}{c}{ Pia Terhadap Tempat } \\
\hline \multirow{3}{*}{ No } & Pernyataan & $\begin{array}{c}\text { Total } \\
\text { Skor }\end{array}$ & $\begin{array}{c}\text { Persentase } \\
(\%)\end{array}$ & Kategori \\
\hline \multirow{3}{*}{1} & Proses Distribusi & 158 & 80 & Sangat Puas \\
2 & Jasa Pesan Antar & 148 & 85,40 & Sangat Puas \\
3 & Lokasi Strategis & 144 & 77,83 & Puas \\
& Jumlah & 450 & 243,23 & \\
& Rata-rata & 150 & 81,07 & Sangat Puas \\
\hline \multicolumn{4}{l}{ Sumber : Diolah dari data primer, 2019 } &
\end{tabular}

Tabel 16 menunjukkan bahwa rata-rata tanggapan responden terhadap Tempat adalah $81,07 \%$ dengan kriteria sangat puas. Indikator tempat yang memperoleh penilaian yang tinggi dari responden adalah jasa pesan antar yaitu $85,40 \%$ dengan kriteria sangat puas sedangkan indikator tempat yang memperoleh penilaian yang rendah dari responden lokasi yaitu 77,83\% dengan kriteria puas.

\section{Promosi (Promotion)}

\section{Upaya Produsen Memperkenalkan Kue Pia Anyen \\ Hasil penelitian menurut responden} mengenai upaya produsen dalam memperkenalkan kue pia ANYEN dapat dilihat pada Tabel 17.

Tabel 17. Penilaian Responden terhadap Upaya Memperkenalkan Kue Pia Anyen

\begin{tabular}{lcccc}
\hline Jawaban & Skor & $\begin{array}{c}\text { Jumlah } \\
\text { Responden }\end{array}$ & $\begin{array}{c}\text { Persentase } \\
(\%)\end{array}$ & $\begin{array}{c}\text { Total } \\
\text { Skor }\end{array}$ \\
\hline Sangat Puas & 5 & 8 & $22 \%$ & 40 \\
Puas & 4 & 9 & $24 \%$ & 36 \\
Cukup Puas & 3 & 11 & $30 \%$ & 33 \\
Tidak Puas & 2 & 7 & $19 \%$ & 14 \\
Sangat Tidak Puas & 1 & 2 & $5 \%$ & 2 \\
\hline Total & 37 & $100 \%$ & 125 \\
\hline Sumber: Diolah dari data primer 2019
\end{tabular}

Sumber: Diolah dari data primer 2019 
Tabel 17 menunjukkan bahwa 8 responden $(22 \%)$ memilih sangat puas, 9 responden (24\%) memilih puas, 11 responden $(30 \%)$ memilih cukup puas, 7 responden (19\%) memilih tidak puas, dan 2 responden $(5 \%)$ memilih sangat tidak puas. Dengan skor yaitu 125 .

$\frac{125}{185} \times 100 \%=67,56 \%$ Skor tersebut berada di kriteria puas dengan persentase $67,56 \%$.

\section{Media Promosi}

Promosi adalah upaya untuk memberitahukan atau menawarkan produk atau jasa pada calon konsumen untuk membeli atau mengkonsumsinya.

Tabel 18. Penilaian Responden terhadap Media Promosi Yang Digunakan

\begin{tabular}{lcccc}
\hline Jawaban & Skor & $\begin{array}{c}\text { Jumlah } \\
\text { Responden }\end{array}$ & $\begin{array}{c}\text { Persentase } \\
(\%)\end{array}$ & $\begin{array}{c}\text { Total } \\
\text { Skor }\end{array}$ \\
\hline Sangat Puas & 5 & 5 & $14 \%$ & 25 \\
Puas & 4 & 9 & $24 \%$ & 36 \\
Cukup Puas & 3 & 12 & $32 \%$ & 36 \\
Tidak Puas & 2 & 9 & $24 \%$ & 18 \\
Sangat Tidak & 1 & 2 & $5 \%$ & 2 \\
Puas & & 37 & $100 \%$ & 117 \\
\hline Total & & &
\end{tabular}

Sumber: Diolah dari data primer, 2019

Tabel 18 menunjukkan bahwa 5 responden (14\%) memilih sangat puas, 9 responden $(24 \%)$ memilih puas, 12 responden (32\%) memilih cukup puas, 9 responden (24\%) memilih tidak puas, dan 2 responden (5\%) memilih sangat tidak puas. Dengan skor total yaitu 117.

$\frac{117}{185} \times 100 \%=63,24 \%$ Media promosi berada di kriteria puas.

\section{Promosi Langsung Pada Konsumen}

Tabel 19 menunjukkan bahwa 16 responden $(43 \%)$ memilih sangat puas, 20 responden $(54 \%)$ memilih puas, dan 1 responden (3\%) memilih cukup puas. Dengan skor total yaitu 163 .

$\frac{163}{185} \times 100 \%=85,10 \%$ Skor berada di kriteria sangat puas yaitu $85,10 \%$.
Tabel 19. Penilaian Responden Terhadap Promosi Langsung Pada Konsumen

\begin{tabular}{lcccc}
\hline Jawaban & Skor & $\begin{array}{c}\text { Jumlah } \\
\text { Responden }\end{array}$ & $\begin{array}{c}\text { Persentase } \\
(\%)\end{array}$ & $\begin{array}{c}\text { Total } \\
\text { Skor }\end{array}$ \\
\hline Sangat Puas & 5 & 16 & $43 \%$ & 80 \\
Puas & 4 & 20 & $54 \%$ & 80 \\
Cukup Puas & 3 & 1 & $3 \%$ & 3 \\
Tidak Puas & 2 & 0 & $0 \%$ & 0 \\
Sangat Tidak Puas & 1 & 0 & $0 \%$ & 0 \\
\hline Total & 37 & $100 \%$ & 163 \\
\hline
\end{tabular}

Sumber: Diolah dari data primer, 2019

Bauran Pemasaran Kue Pia Terhadap Promosi

\begin{tabular}{llccc}
\hline No & Peruyataan & $\begin{array}{c}\text { Total } \\
\text { Slkor }\end{array}$ & $\begin{array}{c}\text { Presentase } \\
(\mathbf{9} \%)\end{array}$ & Kategori \\
\hline 1 & Upaya Nemperkenalkan Produk & 125 & 67.56 & Puas \\
2 & Media Promosi & 117 & 63,24 & Puas \\
& Promosi Langsung (Produsen- & & & Sangat \\
3 & Konsumen) & 163 & 85,10 & Puas \\
& Jumlah & 405 & 243,23 & Puas \\
\hline Rata-rata & 135 & 71,97 & \\
\hline Sumber : Diolah daridata primer, 2019 & & &
\end{tabular}

Tabel 20 menunjukkan bahwa hasil rata-rata penilain responden yaitu $71,97 \%$ dengan kriteria sangat puas.

\section{. KESIMPULAN DAN SARAN}

\section{Kesimpulan}

Hasil penelitian menunjukkan penilaian responden terhadap produk bauran pemasaran ialah 78,61\% dengan kategori puas, aspek harga $85,97 \%$ dengan kategori sangat puas, aspek tempat $81,07 \%$ dengan kategori sangat puas, dan aspek promosi $71,97 \%$ dengan penilain terendah dari aspek yang lainnya dengan kategori puas.

\section{Saran}

Hasil penelitian diharapkan dapat menjadi acuan untuk meningkatkan strategi pemasaran Anyen khususnya dalam aspek promosi yaitu dengan mempromosikan kue pia lewat media sosial atau media cetak.

\section{DAFTAR PUSTAKA}

Hasanudin, R. 2004. Pengantar Ekonomi Pertanian, Prehalindo. Yogyakarta Hassanidin, 2005. Konsumen Dan Strategi Pemasaran, Prehallindo. Jakarta. 
Irawan dan Handi 2002. Pemasaran, Prinsip ddan kasus, Edisi Kedua, BPFE Yogyakarta.

Kotler, dan Amstrong. 2001. Prinsip-Prinsip Pemasaran Jilid 1. Erlangga. Jakarta.

Kotler, Philip dan AB. Susanto. 2000. Manajemen Pemasaran. Analisis Perencanaan, Implementasi dan Pengendalian. Salemba Empat. Yogyakarta.

Kottler dan Amstrong. 2002. Fungsi Ekonomi, Jakarta.
Lupioadi, Rambat. 2001. Manajemen dan Pemasaran. Salemba Empat. Jakarta Stanton, F. R. 2003. Manajemen PemasaranJasa. Banyumedia Publishing. Malang.

Swasta, Basu dan Irawan. 1990. Manajemen Pemasaran Modern. Liberty. Jakarta.

Swasta, Basu. 1991. Asas-Asas Marketing. Liberty. Jakarta. 